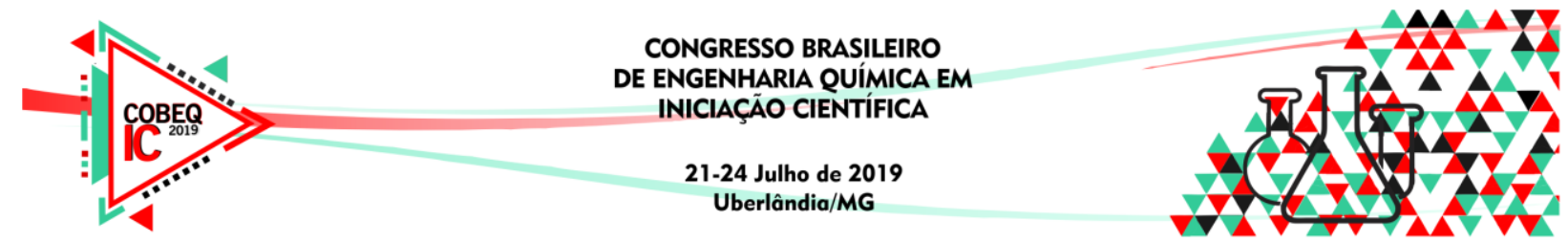

\title{
CARACTERIZAÇÃO DE SCOBY DO KOMBUCHA PARA A PRODUÇÃO DE BIOFILMES
}

\author{
P. A. DOMENEGHETTI ${ }^{1}$, M. G. SOARES ${ }^{1}$, V. C. R. SCHMIDT ${ }^{1}$ \\ Universidade Federal de Uberlândia, Faculdade de Engenharia Química \\ E-mail para contato: poliana.domeneghetti@hotmail.com
}

\begin{abstract}
RESUMO - O meio ambiente vem sofrendo muito com os materiais poliméricos descartados no solo, pois demoram para se degradarem além de ter a capacidade de produzir resíduos muito tóxicos a terra. Uma solução para o problema ambiental dos plásticos pode ser o SCOBY (Symbiotic Culture of Bacteria and Yeasts). Desta maneira, o objetivo do trabalho foi caracterizar o SCOBY, identificando seu potencial celulósico, assim como, analisar se será possível utilizar esse material para produzir filmes biodegradáveis. Para isso, foi preciso preparar o chá kombucha e adicionar uma colônia de SCOBY para fermentação e posteriormente secagem. Em seguida, foi realizado testes para identificar os teores de lignina klason insolúvel, celulose, holocelulose, hemicelulose e $\alpha$-celulose que existe no material. Os resultados observados foram 4,09\% de $\alpha$-celulose, $8,96 \%$ de holocelulose, 4,89\% de hemicelulose, 9,55\% de lignina klason insolúvel e $0,0083 \%$ de lignina klason solúvel. Pelo teor de celulose e holocelulose apresentado, conclui-se que o SCOBY pode ser utilizado para elaborar filmes biodegradáveis e substituir os materiais poliméricos.
\end{abstract}

\section{INTRODUÇÃO}

Até pouco tempo atrás era importante descobrir materiais poliméricos cada vez mais duráveis para utilização diária em várias aplicações. Isto devido as suas propriedades mecânicas e versatilidade de uso. Os plásticos são poucos degradáveis e quando descartados no meio ambiente geram contaminação do solo e grande quantidade de resíduos (Franchetti et al., 2006).

Por isso, pesquisadores e indústrias tem procurado alternativas para minimizar estes impactos ambientais, sendo que filmes biodegradáveis podem substituir plásticos, devido sua viabilidade técnica e econômica (Brito et al., 2011). Há diversos trabalhos com polissacarídeos, proteínas e celulose bacteriana como componentes de matriz polimérica.

Neste sentido, o SCOBY (Symbiotic Culture of Bacteria and Yeasts) surge como uma alternativa para o meio ambiente. Este é elaborado da fermentação do chá verde e preto, conhecida como Kombucha, extrato doce de origem asiática e ligeiramente gaseificada. $\mathrm{O}$ SCOBY é uma membrana celulósica associada a bactérias simbiótica (bactérias acéticas e leveduras) que realizam várias reações bioquímicas durante o tempo de obtenção da bebida (Paludo, 2017). 


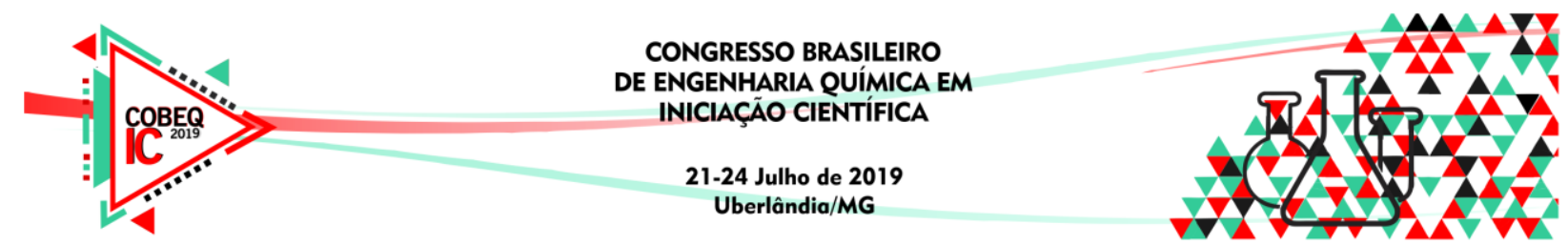

Assim, o objetivo deste projeto foi identificar o potencial de celulose existente no SCOBY para desenvolver novos materiais biodegradáveis que substituíssem os polímeros sintéticos existentes.

\section{MATERIAIS E MÉTODO}

O SCOBY é uma película gelatinosa que se forma na superfície do chá kombucha e é obtido a partir de sua fermentação. Assim na fermentação, a película se acumula na parte superior do meio (em contato com o ar), como observado na figura 1 (Jarrell et al., 2000). Uma amostra do kombucha com o SCOBY foi recebido de doação. Para replicar, $1 \mathrm{~L}$ de água com 12,5g de chá preto e 12,5g de chá verde destilada foram fervidos por 10 minutos. Após, adicionou-se $125 \mathrm{~g}$ de açúcar cristal branco (sacarose) para ser dissolvida no chá ainda quente até a completa homogeneização. Para resfriar, 1L de água destilada gelada foi adicionado e $300 \mathrm{~g}$ da cultura starter SCOBY colocado à mistura.

A fermentação ocorreu em recipiente de vidro coberto com tecido de algodão, para o contato com o oxigênio, necessário a fermentação. Os frascos foram mantidos temperatura controlada de $\left(25^{\circ} \mathrm{C}\right)$ em incubadora de Demanda Bioquímica de Oxigênio (DBO) por 22 dias para a condução do processo fermentativo.

Figura 1 - Chá kombucha fermentado com a formação de SCOBY.

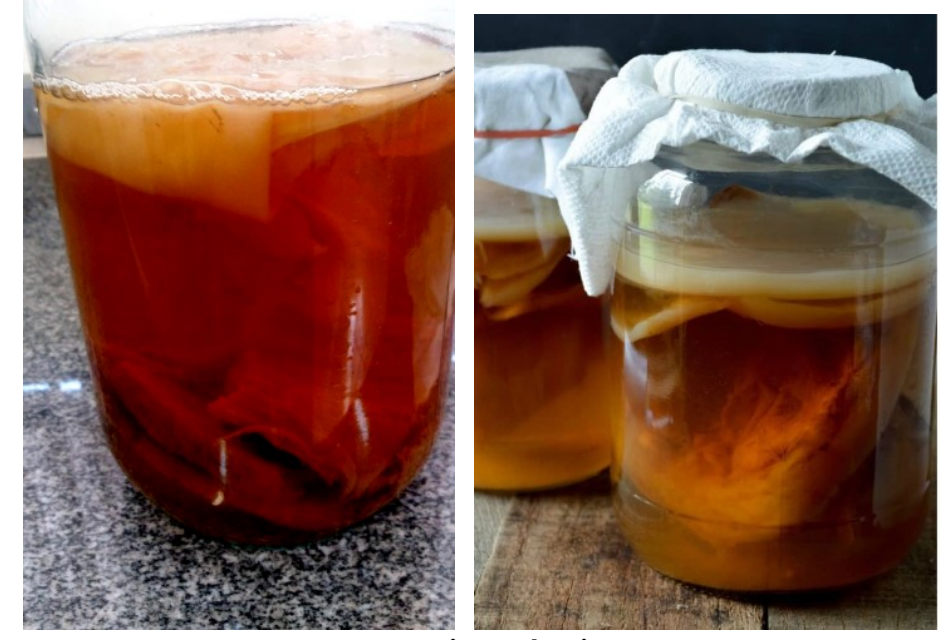

Fonte: Autoria própria

Após, SCOBY foram retirados e secos em estufa de circulação de ar a $50^{\circ} \mathrm{C}$ por 10 horas. Para avaliar sua composição, a determinação do teor de lignina Klason insolúvel foi realizada seguindo a norma TAPPI T13M-54 modificada (Silva et al., 2016). O procedimento para obtenção da celulose e holocelulose foi realizado pelo método do clorito ácido com algumas modificações como descrito por Silva et al (2016). O conteúdo de hemiceluloses foi determinado como a percentagem da diferença entre os teores de holocelulose e $\alpha$-celulose em relação a massa inicial de amostra seca, levando em conta o rendimento calculado na obtenção da holocelulose. 


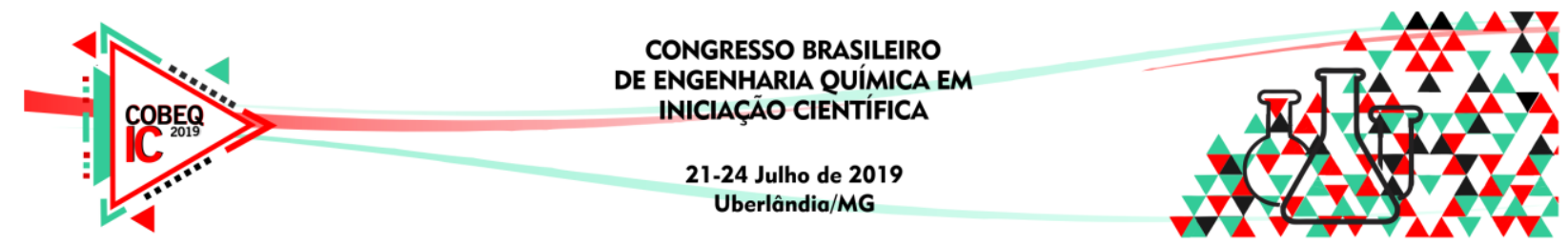

\section{RESULTADOS}

O SCOBY obtido por fermentação pode ser observado na Figura 2A. Para a obtenção do material biodegradável o material seco é apresentado na Figura 2B. Por ser um material obtido por via biotecnológica, sua espessura varia de acordo com o tempo de fermentação, porém para atingir esses resultados é preciso cultiva-lo a temperatura controlada e mantê-lo sem contaminação.

Figura 2 - SCOBY A) obtido com 10 dias de fermentação e B) secos em estufas.
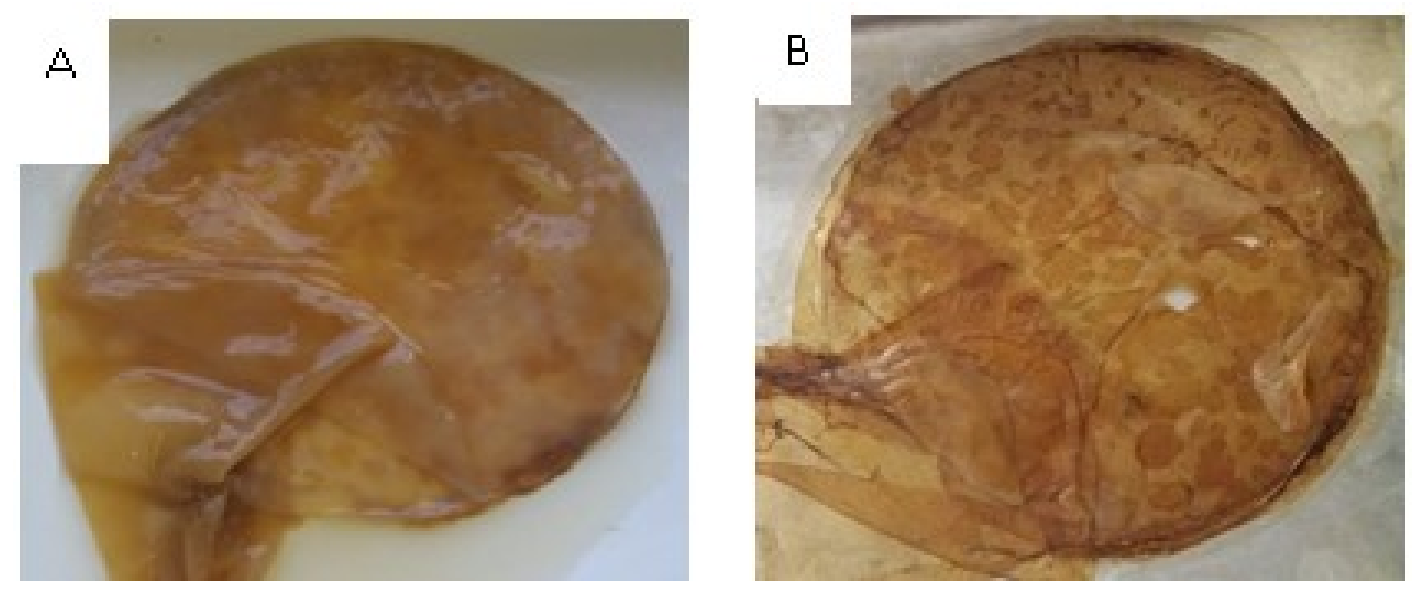

A tabela 1 apresenta os resultados da composição química do SCOBY. Segundo esses resultados observa-se que a membrana de celulose apresenta quantidade de $18 \%$, aproximadamente, de lignina klason insolúvel e holocelulose. Valores menores de $\alpha$-celulose e hemicelulose, sendo que a lignina klason solúvel ficou próxima de zero. Não há estudo de avaliação do SCOBY quanto à composição química. Segundo Lima et al. (2015) fibras naturais, apesar de ser a principal fonte de celulose devido a sua abundância natural, ao serem utilizados com fonte para a extração de nanocristais, requerem um pré-tratamento de purificação para retirada de lignina e hemicelulose e esse processo é poluente e de alto custo. Neste caso a celulose bacteriana surge como excelente alternativa, pois como citado é livre de impurezas, além de ser altamente cristalina e obtida em escalas comerciais.

Tabela 1 - Composição química do SCOBY.

\begin{tabular}{|l|l|}
\hline compostos (\%) & SCOBY \\
\hline$\alpha$-celulose & $4,09 \pm 0,55$ \\
\hline Holocelulose & $8,96 \pm 1,61$ \\
\hline Hemicelulose & $4,89 \pm 1,09$ \\
\hline Lignina Klason Insolúvel & $9,55 \pm 2,53$ \\
\hline Lignina Klason Solúvel & $0,0083 \pm 0,00024$ \\
\hline
\end{tabular}




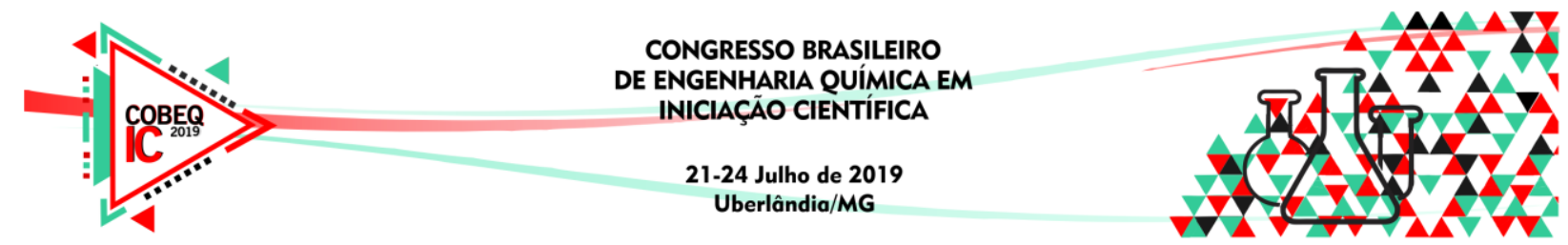

Assim, podemos analisar que o SCOBY apresenta composição de fibras favoráveis para a fabricação de embalagens resistentes, por exemplo, a holocelulose. Nesse contexto, os trabalhos que elaboram materiais biodegradáveis, como Pereira (2010) extração de nanocelulose a partir de fibras vegetais para produzir embalagens biodegradáveis e Rodrigues et al. (2015) fabrica papel biodegradável através da retirada de celulose solúvel do inter de algodão encontraram quantidades semelhantes ao reportado neste estudo. Portanto, os resultados da composição química do SCOBY apresentam potencial de celulose, mostrando que o material já possui este componente livre em sua estrutura, não estando ligada a lignina e hemicelulose como no caso de fibras de fontes vegetais.

\section{CONCLUSÃO}

A composição química do SCOBY apresentou valor que permitem que ele possa ser utilizado no desenvolvimento de novos materiais. Sendo assim, é uma alternativa que pode ser pesquisada como substituto do plástico.

\section{AGRADECIMENTOS}

Os autores gostariam de agradecer ao CNPq, à CAPES, à FAPEMIG (Brasil) e à Universidade Federal de Uberlândia pelo apoio durante todo o trabalho.

\section{REFERÊNCIAS}

BRITO, G. F.; AGRAWAL, P.; ARAÚJO, E. M.; MÉLO, T. J. A.. Biopolímeros, Polímeros Biodegradáveis e Polímeros Verdes. Revista Eletrônica de Materiais e Processos, ISSN 1809-8797, v.6.2, p.127-139, 2011.

FRANCHETTI, S. M. M.; MARCONATO, J. C.. Polímeros biodegradáveis - uma solução parcial para diminuir a quantidade dos resíduos plásticos. Rio Claro: Química Nova, v.29, n.4, p.811-816, 2006.

JARRELL, J.; Cal, T.; BENNETT, J. W.. The Kombucha consortia of yeasts and bacteria. Mycologist, p.166-70, 2000.

LIMA, L. R.; SANTOSA, D. B.; SANTOSA, M. V.; BARUDA, H. S., HENRIQUE, M. A.; PASQUINI, D.; PECORARO, E.; RIBEIRO, S. J. L. Cellulose nanocrystals from bacterial celulose. Quim. Nova, Vol. 38, No. 9, 1140-1147, 2015.

PALUDO, N. Desenvolvimento e caracterização de kombucha obtida a partir de chá verde e extrato de erva-mate: processo artesanal e escala laboratorial. Porto Alegre, Instituto de Ciência e Tecnologia de Alimentos da Universidade Federal do Rio Grande do Sul, 2017.

PEREIRA, A. L. S.. Extração de nanocelulose de fibras vegetais. Universidade Federal do Ceará, Fortaleza, 2010. 
RODRIGUES, C. H. F.; SOUZA, V. J. C.; CARASCHI, J. C.. Estudo da potencialidade do línter de algodão para a produção de celulose solúvel. Unesp, XXVIII Congresso de Iniciação Científica da Unesp, 2015.

SILVA, T. A. L. et al.. Avaliação do efeito da explosão a vapor catalisada por NaOH na composição química e estrutural do bagaço de cana-de-açúcar. Programa de PósGraduação em Biocombustíveis: UFU, 2016.

SOUZA, F. R. B. Síntese e caracterização de hemiceluloses catiônicas a partir do reaproveitamento da palha de milho. DISSERTAÇÃO de Mestrado (Programa de PósGraduação em Química) Uberlândia, MG, 2016. 